\title{
Delayed metabolism of human brain natriuretic peptide reflects resistance to neutral endopeptidase
}

\author{
M W Smith ${ }^{1}$, E A Espiner ${ }^{1,2}$, T G Yandle ${ }^{1}$, C J Charles ${ }^{2}$ \\ and $\mathbf{A} \mathbf{M}$ Richards $^{2}$ \\ ${ }^{1}$ Department of Endocrinology, Christchurch Hospital, Christchurch, New Zealand \\ ${ }^{2}$ Department of Medicine, Christchurch School of Medicine, Christchurch, New Zealand \\ (Requests for offprints should be addressed to E A Espiner, Department of Endocrinology, Christchurch Hospital, Private Bag, Christchurch, New Zealand; \\ Email: eric.espiner@chmeds.ac.nz)
}

\begin{abstract}
Metabolism of natriuretic peptides is regulated by two degradative pathways: uptake by the clearance receptor (natriuretic peptide receptor C - NPR-C) and hydrolysis by neutral endopeptidase (NEP). Affinity studies favour a dominant role of NPR-C in hormone degradation in several species but do not account for the efficacy of NEP inhibitors in vivo, nor the uniquely prolonged half life $\left(t_{1 / 2}\right)$ of human brain natriuretic peptide (hBNP). Postulating that (1) delayed metabolism of $\mathrm{hBNP}$ reflects resistance to NEP and (2) interactions between NPR-C and NEP increase enzyme activity, we have used purified ovine and human NEP, plus ovine lung plasma membranes to study the relative importance of receptor and enzyme pathways. We have also related the findings to hormone metabolism
\end{abstract}

in vivo. Binding affinities of atrial natriuretic peptide (ANP), hBNP and ovine BNP (oBNP) to oNPR-C were similar $\left(K_{\mathrm{d}}=8-16 \mathrm{pM}\right)$. In contrast, unlike ANP and oBNP, hBNP was not significantly degraded by purified oNEP or plasma membranes. Despite similar (and high) affinity of oNPR-C for oBNP and hBNP, the $t_{1 / 2}$ of hBNP $(12.7 \mathrm{~min})$ was more than fourfold that of oBNP ( $2.6 \mathrm{~min})$. Although we found no evidence for receptorenzyme interaction, our results show that the delayed metabolism of hBNP reflects resistance to NEP. These findings have important implications for future treatment strategies in human disease.

Journal of Endocrinology (2000) 167, 239-246

\section{Introduction}

The natriuretic peptides atrial natriuretic peptide (ANP) and brain natriuretic peptide (BNP) are circulating hormones of cardiac origin involved in the regulation of extracellular fluid and blood pressure homeostasis (Espiner et al. 1995). Several effects of ANP and BNP, including natriuresis, vasodepression, inhibition of renin and aldosterone and shrinkage of plasma volume, are related to the natriuretic peptide hormone concentration in blood, which is itself the net outcome of cardiac secretion and disappearance from plasma (Espiner et al. 1995). Regulation of natriuretic peptide secretion from the heart has been studied extensively but much less is known of the mechanisms affecting disappearance of these hormones from the circulation. Total body clearance of ANP or BNP appears to be determined by two major pathways: binding and internalisation via the non guanyl cyclase linked natriuretic peptide receptor C (NPR-C) (Maack et al. 1993) and enzymatic degradation by the extracellular membrane-bound metalloproteinase neutral endopeptidase (NEP) EC 24.11 (Kenny et al. 1993). The relative importance of these two degradative pathways is controversial (Espiner et al. 1995). Early studies in rats on ANP disappearance from plasma (Okolicany et al. 1992) showed that the clearance receptor pathway was the most important degradative route since not only was there an excess of spare (unoccupied) receptors at physiological plasma concentrations (Maack et al. 1993) but, more importantly, the affinity of ANP for NPR-C (affinity constant, $K_{\mathrm{d}}$, picomolar) (Suga et al. 1992), was several orders of magnitude greater than that reported for the purified NEP $\left(K_{\mathrm{m}}\right.$ or $K_{\mathrm{i}}$, micromolar) extracted from tissues (Kenny et al. 1993). Surprisingly, however, specific inhibitors of NEP increase endogenous levels of ANP in several species (Ruskoaho 1992), suggesting an important role for the enzyme in the regulation of natriuretic peptides even at physiological concentrations. How the enzyme impacts on the regulation of natriuretic peptides, in view of the above affinities, is quite unexplained.

Despite the physiological importance (Espiner et al. 1995) and predictive value (Richards et al. 1999) of BNP in human cardiovascular disorders, the metabolism of BNP has been even less well studied than that of ANP. What is clear, however, is the uniquely prolonged disappearance rate $\left(t_{1 / 2}\right)$ of human BNP-32 (hBNP) from plasma in 
humans (Holmes et al. 1993), compared with the uniformly rapid clearance of other natriuretic peptides in humans and in other species (Ruskoaho et al. 1992, Charles et al. 1996a), findings which remain unexplained. The aim of the present study was therefore to explore mechanisms accounting for the uniquely delayed metabolism of hBNP. Although not studied previously there is circumstantial evidence that the difference in the metabolism of species-specific BNP forms in vivo reflects the summative effects of receptor binding and enzyme hydrolysis (Charles et al. 1996b, Rademaker et al. 1997). Concerning the former, the affinity of NPR-C for BNP is predicted by the amino acid sequence of the receptor: Ileu at position 188 (as in hNPR-C) reduces the affinity for hBNP (but not for ANP or ovine/porcine BNP) when compared with rat NPR-C where alanine substitutes for Ileu (Engel et al. 1994). These findings may explain in part the shorter $t_{1 / 2}$ of ovine BNP (oBNP) in humans (McGregor et al. 1990) when compared with hBNP. Whether variations in the affinity of the enzyme for BNP forms (or turnover rate) affect half life is unknown. Compared with oBNP, hBNP is a less favoured substrate for both porcine (Kenny et al. 1993) and human (Watanabe et al. 1997) endopeptidase, raising the possibility that the uniquely prolonged $t_{1 / 2}$ of $\mathrm{hBNP}$ in humans reflects lower affinities for both NPR-C and enzyme. Because in sheep oBNP is rapidly metabolised (Charles et al. 1996a) - suggesting the presence of Ala at 188 in the ovine NPR-C, as in rat - we predicted that comparative studies of BNP metabolism in sheep may distinguish the separate effects of receptor and enzyme. Accordingly we have used purified ovine and human NEP, and freshly prepared cell membranes from ovine lungs - tissue known to be important in natriuretic peptide clearance and metabolism (Bates et al. 1989, Hollister et al. 1989) - to characterise the relative importance of the receptor and enzymatic pathways, and to relate the findings to the disappearance of ANP/BNP from plasma in vivo in two species (human and sheep) exhibiting differing patterns of BNP metabolism. We have also tested the hypothesis that interactions occur between the receptor and enzyme such that the hormone is more effectively cleaved by NEP once bound to NPR-C. Our findings show for the first time that the uniquely delayed metabolism of hBNP is in fact related to its resistance to the enzyme. No support for receptor-enzyme interaction was found. Taken together, these findings have important implications for future treatment strategies enhancing BNP bioactivity in humans.

\section{Materials and Methods}

\section{Reagents}

Tris (Tris (hydroxymethyl) methylamine), TFA (trifluoroacetic acid) and sucrose were purchased from $\mathrm{BDH}$
Chemicals (Palmerston North, New Zealand). ANP, hBNP (human BNP-32), oBNP (= porcine BNP-26), C-ANP(4-23) (Des[Gln $\left.{ }^{18}, \operatorname{Ser}^{19}, \mathrm{Gly}^{20}, \mathrm{Leu}^{21}, \mathrm{Gly}^{22}\right]-$ ANF 4-23- $\mathrm{NH}_{2}$ (rat)) and phosphoramidon were purchased from Peninsula Laboratories, San Carlos, CA, USA. Leupeptin, phenylmethylsulphanyl fluoride (PMSF) and polyethylenimine were purchased from Sigma Chemicals, St Louis, MO, USA. SCH39370 and SCH32615 were kindly provided by Schering Plough, Bloomfield, NJ, USA.

\section{Preparation of ovine lung plasma membranes}

Ovine lung membranes were prepared according to the method of Maeda (Maeda et al. 1983). In brief, tissue was homogenised in two volumes (wt/vol.) of 'homogenisation buffer' (50 mM Tris-HCl, 0.15 M NaCl, 0.1 mM PMSF, $5 \mathrm{mM} \mathrm{MgCl}, 1 \mu \mathrm{g} / \mathrm{ml}$ leupeptin; $\mathrm{pH} 7 \cdot 4$ ), centrifuged at $9500 \mathrm{~g}$ and the supernatant then layered over a sucrose pad $(41 \%)$ and centrifuged $(8500 \mathrm{~g})$ for $1 \mathrm{~h}$. The membrane layer at the interface was then aspirated, centrifuged at $140000 \mathrm{~g}$ and the resulting pellet re-suspended. After further washes the product was suspended in 'homogenisation buffer', aliquoted and stored at $-80{ }^{\circ} \mathrm{C}$. Purification of the lung membrane preparation was monitored by measuring the specific activity of plasma membrane markers (NEP and angiotensin converting enzyme (ACE)), and glucose 6-phosphatase as a marker of endoplasmic reticulum. From crude homogenate to final purified membrane preparation, there was a fourfold increase in ACE, a 13-fold increase in NEP and a fall to zero (undetectable) in glucose 6-phosphatase.

\section{Natriuretic peptide receptor assay}

Lung membranes $(0.02 \mathrm{mg}$ protein $/ \mathrm{ml}$ final concentration) were equilibrated for $20-24 \mathrm{~h}$ at $4{ }^{\circ} \mathrm{C}$ with 15000 c.p.m. ${ }^{125}$ I-ANP and unlabelled peptide ANP, hBNP, oBNP, C-ANP(4-23), each 5-15000 pg in radio-receptor assay buffer ('homogenisation buffer' with $2 \times 10^{-5} \mathrm{M}$ phosphoramidon and $0 \cdot 1 \% \mathrm{BSA}$ ). Bound radioactivity was collected onto polyethylenimine-treated glass fibre paper (Whatman GF/C paper pre-soaked in 1\% polyethylenimine for $120 \mathrm{~min}$ ), washed with $0.15 \mathrm{M}$ $\mathrm{NaCl}$, and counted in a gamma counter. Non-specific binding was measured in the presence of an excess of ANP (15000 pg). Displacement curves were fitted, and $K_{\mathrm{d}}$ values calculated, using the computer program LIGAND (Munson \& Rodbard 1980). A single receptor site analysis gave the best fit and was used for determining all $K_{\mathrm{d}}$ values.

Monoclonal antibody to NPR-C

Purified monoclonal antibody (Porter et al. 1993) (CR.203.5A, Scios Nova, CA, USA) to the hNPR-C was 
donated by Dr Gordon Porter, Scios Nova, Mountain View, CA, USA. Antibodies were raised using a recombinant vaccinia virus expressing hNPR-C cDNA, and assessed for ability to inhibit ${ }^{125}$ I-ANP binding to a purified preparation of truncated $\mathrm{hNPR}-\mathrm{C}\left(\mathrm{IC}_{50}=\right.$ $\left.4.7 \times 10^{-5} \mathrm{mg} / \mathrm{ml}\right)$.

\section{Purified endopeptidase 24.11}

Purified preparations of ovine and hNEP from kidney extracts (Kittelberger \& Neale 1990) were kindly donated by Drs Paul Davis and R Kittelberger, Wellington School of Medicine, Wellington, New Zealand. These preparations gave single bands on gel electrophoresis and both enzymes were recognised by antiserum to NEP. Further studies in our laboratory revealed that both enzyme preparations exhibited NEP activity when measured in our NEP assay (Yandle et al. 1992) and were inhibited by specific inhibitors of NEP, including phosphoramidon, SCH 39370 (Yandle et al. 1992) and SCH32615 (Charles et al. 1996b).

\section{HPLC analysis}

Incubates were centrifuged and the supernatant injected on to a $22.5 \mathrm{~cm}$ Brownlee RP300 cartridge column at $40{ }^{\circ} \mathrm{C}$ with a flow rate of $1 \mathrm{ml} / \mathrm{min}$. Peptides were eluted with a gradient of $15-45 \%$ acetonitrile in $0.1 \%$ TFA over $30 \mathrm{~min}$. Eluted peptides were detected using u.v. absorbance at $210 \mathrm{~nm}$. Where ${ }^{125} \mathrm{I}$-ANP was included, the eluate was also collected in fractions $(0.5 \mathrm{ml})$ which were counted in a gamma counter.

\section{Hydrolysis of ANP by NEP, and influence of receptor occupancy}

The rate of hydrolysis of ANP by intact lung membranes was measured in the presence of substrate concentrations close to the enzyme $K_{\mathrm{m}}$. Degradation rates were determined after HPLC from the reduction of intact ${ }^{125}$ I-ANP radioactivity, and by reduction in the peak area of intact unlabelled ANP after separation from metabolites using HPLC with u.v. absorbance. Experimental conditions were established to achieve linear degradation rates of ANP within the incubation period. In brief, lung membrane preparations $(0.003-0.02 \mathrm{mg}$ protein $/ \mathrm{ml})$ were incubated at $37^{\circ} \mathrm{C}$ in incubation buffer $(50 \mathrm{mM}$ Tris $\mathrm{HCl}$, $0 \cdot 15 \mathrm{M} \mathrm{NaCl}, 5 \mathrm{mM} \mathrm{MgCl}, 0.1 \% \mathrm{BSA}, \mathrm{pH} 7 \cdot 4)$ containing unlabelled ANP $(1-150 \mu \mathrm{M})$ and labelled ANP in constant ratio $\left(25 \times 10^{6}\right.$ c.p.m. $\left./ \mu \mathrm{M}\right)$. After $30 \mathrm{~min}$ incubation, the reaction was stopped by the addition to incubates $(100 \mu \mathrm{l})$ of $20 \mu \mathrm{l}$ of $0 \cdot 3 \%$ TFA in $12 \%$ acetonitrile, after which solutions were frozen immediately and stored at $-80^{\circ} \mathrm{C}$. Degradation of ANP due to enzymes other than NEP was negligible $(<2 \%)$, as demonstrated in control incubations in the presence of phosphoramidon, and no hydrolysis was observed in the absence of plasma membranes.

The extent of hydrolysis at each peptide concentration was limited to $<20 \%$ except in the instance of the lowest concentration $(1 \mu \mathrm{M}$ ANP) where hydrolysis was $<28 \%$. The decrease in ANP under the above conditions (as observed by HPLC analysis) was linear over the time period examined (30 min, $r=-0 \cdot 99$ ). The $K_{\mathrm{m}}$ for ANP was calculated from disappearance of the ANP peak as assessed by HPLC using linear regression analysis of $1 / V$ vs $1 / s$ plots where $V$ is the degradation rate and $s$ is the substrate concentration.

\section{Comparative rates of natriuretic peptide degradation}

Comparative degradation rates of the natriuretic peptides (oBNP, hBNP and ANP) were determined by incubating the peptides with ovine lung membrane preparations as well as with purified forms of sheep and human NEP. Peptides $(10 \mu \mathrm{M})$ were incubated with lung membrane preparations or with purified enzyme in incubation buffer as described above. The concentration of NEP in each of the above preparations was standardised according to activity as measured by a fluorometric assay (Yandle et al. 1992). After timed incubations (ANP $30 \mathrm{~min}$, hBNP $120 \mathrm{~min}, \mathrm{oBNP} 60 \mathrm{~min}$ at $37^{\circ} \mathrm{C}$ ), the incubation reaction was stopped by the addition of $0.3 \%$ TFA in $12 \%$ acetonitrile, and samples stored at $-80^{\circ} \mathrm{C}$ prior to HPLC analysis as described above. Specificity of the enzyme hydrolysis was established using phosphoramidon in 'control' incubations for each peptide studied and hydrolysis solely due to NEP was calculated by subtraction. A NEP unit was defined as the amount of NEP needed to release $1 \mathrm{nM} / \mathrm{ml}$ per min of free amidomethylcoumarin (AMC) from the synthetic substrate glutaryl-Ala-Ala-Phe-AMC.

\section{Disappearance of BNP from plasma in vivo}

Two $50 \mathrm{~kg}$ Coopworth ewes were surgically prepared with a Swan-Ganz catheter. The sheep received infusions of both hBNP and o (porcine) BNP (Bachem Torrance CA, USA) with a $2 \mathrm{~h}$ 'washout' between infusions. We have previously shown that the 26 amino acid sequence of oBNP is identical to porcine BNP (Aitken et al. 1994). Infusions of both hBNP and oBNP were administered at a dose of $3.2 \mathrm{pM} / \mathrm{kg}$ per $\min$ for $120 \mathrm{~min}$ via the distal (pulmonary artery) port of the Swan-Ganz catheter. Administered doses were confirmed by assay of an aliquot of the infusate. Blood samples $(10 \mathrm{ml})$ were drawn from the proximal port $15 \mathrm{~min}$ before and immediately prior to commencement of infusions, at 15 min intervals throughout infusion, and then at $1 \mathrm{~min}$ intervals for $10 \mathrm{~min}$ immediately post-infusion and 12.5, 15, 20, 25, 30, 45 and $60 \mathrm{~min}$ post-infusion. Samples were drawn on ice, centrifuged and plasma stored at $-80{ }^{\circ} \mathrm{C}$ prior to assay for 


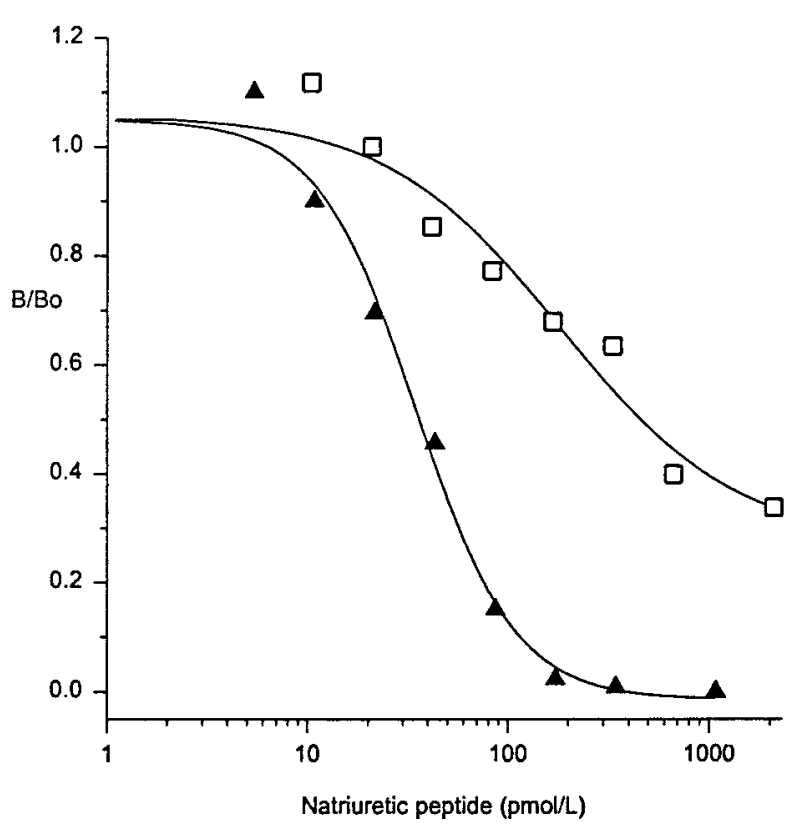

Figure 1 Inhibition of binding of radiolabelled ANP in ovine lung membranes by ANP $(\boldsymbol{\Delta})$ and the NPR-C specific ligand C-ANP(4-23) ( $\square)$.

hBNP (Yandle et al. 1993) and oBNP (Charles et al. 1996a). No significant cross-reactivity of either human or oBNP was detected in ovine or human assays respectively.

Single exponential decay curves $\left(f(x)=a \mathrm{e}^{-b x}+c\right)$ were fitted to the data and the half life calculated from $t_{1 / 2}=0 \cdot 69 / b$.

All experiments on animals or animal tissues were undertaken after approval by the Christchurch School of Medicine Animal Ethics Committee (Christchurch, New Zealand).

\section{Results}

\section{Receptor binding}

After $24 \mathrm{~h}$ incubation at $4{ }^{\circ} \mathrm{C}$, net binding of ${ }^{125} \mathrm{I}-\mathrm{ANP}$ in lung membrane preparations averaged $26 \%$ and $6 \%$ in the presence and absence of phosphoramidon respectively. HPLC analysis of incubation products confirmed that labelled ANP was $>90 \%$ degraded in the absence of phosphoramidon, and that degradation was prevented by its inclusion. All binding studies were therefore undertaken in the presence of phosphoramidon.

As shown in Fig. 1 addition of the specific NPR-C ligand, C-ANP(4-23) progressively reduced the net binding of ${ }^{125}$ I-ANP. Approximately $70 \%$ displacement of labelled ANP was observed at C-ANP(4-23) concentrations of $1000 \mathrm{pM} / 1$. Similarly, the addition of monoclonal antibody to hNPR-C greatly reduced net

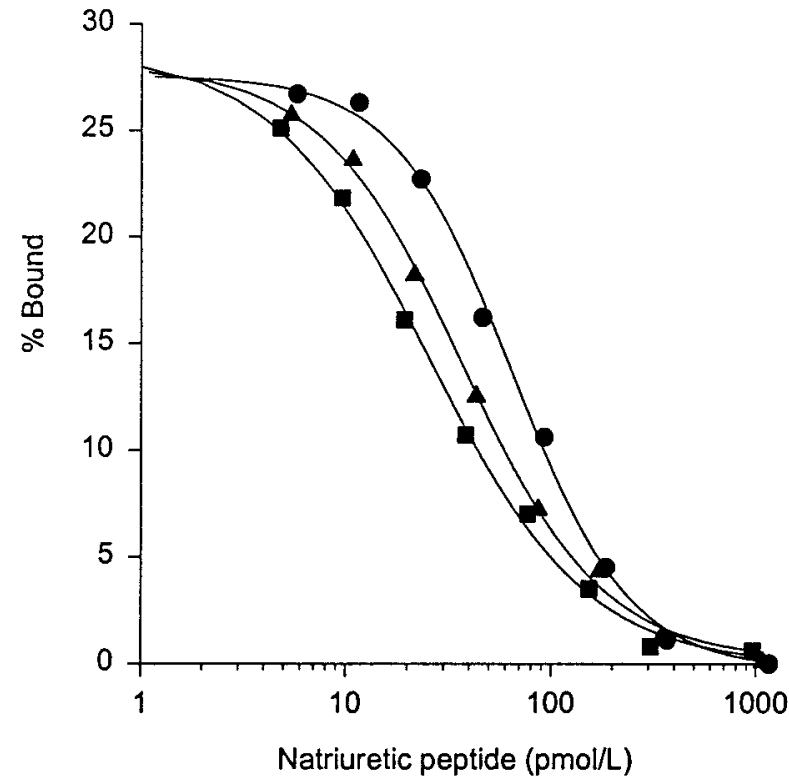

Figure 2 Inhibition of binding of radiolabelled ANP by ovine (porcine) BNP $(\bullet), \operatorname{ANP}(\boldsymbol{\Delta})$ and human BNP $(\boldsymbol{\square})$ in ovine lung membranes.

binding from 29\% (control) to 9\% (data not shown), whereas a non-immune extract had no effect. Taken together these findings indicate that $70 \%$ of the binding of labelled ANP in the ovine lung membrane preparation is attributable to NPR-C receptors.

Representative binding displacement curves for ANP, hBNP and oBNP are shown in Fig. 2. Displacement curves (undertaken on three different occasions) were similar for all three peptides which completely displaced labelled ANP at high concentrations. Calculated $K_{\mathrm{d}}$ values were 8,10 and $16 \mathrm{pM}$ respectively for hBNP, ANP and oBNP.

\section{NEP}

Assay conditions were established that gave linear reaction rates over the substrate concentration ranges used, and reaction velocities (calculated on the basis of decrease in radioactivity associated with the ANP peak), were in close agreement with values obtained from u.v. absorption measurements. Interference by receptor binding in these determinations is unlikely as the substrate (ANP) concentrations $(1-150 \mu \mathrm{M})$ - at which the $K_{\mathrm{m}}$ measurement was made - were more than sufficient to saturate NPR-C receptors (ANP concentration $10^{6}$ fold that of the receptor $K_{\mathrm{d}}$ concentration).

The $K_{\mathrm{m}}$ for the ovine enzyme acting on ANP in intact lung membranes was $10 \mu \mathrm{M}$, similar to that reported for the solubilized enzyme (Kenny et al. 1993), and therefore 
Table 1 Relationship of $t_{1 / 2}$ to NEP and NPR-C characteristics in sheep and humans

\begin{tabular}{|c|c|c|c|c|c|c|}
\hline & \multicolumn{3}{|l|}{ Sheep } & \multicolumn{3}{|l|}{ Humans } \\
\hline & $\begin{array}{l}\mathrm{NEP}^{\mathrm{a}} \\
(\mathrm{pmol} / \mathrm{min})\end{array}$ & $\begin{array}{l}\text { NPR-C }{ }^{b} \\
\left(k_{d}, p M\right)\end{array}$ & $\begin{array}{l}t_{1 / 2} \\
(\mathrm{~min})\end{array}$ & $\begin{array}{l}\mathrm{NEP}^{\mathrm{a}} \\
(\mathrm{pmol} / \mathrm{min})\end{array}$ & $\begin{array}{l}\text { NPR-C } \\
\left(k_{d}, p M\right)\end{array}$ & $\begin{array}{l}t_{1 / 2} \\
(\mathrm{~min})\end{array}$ \\
\hline ANP & $0 \cdot 24$ & 10 & 3 & $0 \cdot 48$ & 10 & $3 \cdot 1$ \\
\hline oBNP & 0.08 & 16 & $2 \cdot 6$ & $0 \cdot 20$ & 11 & $3 \cdot 1$ \\
\hline hBNP & 0.01 & 8 & $12 \cdot 7$ & $0 \cdot 02$ & 140 & 22 \\
\hline $\begin{array}{l}\text { Degrad } \\
\text { Measur } \\
\text { Measur } \\
\text { he half } \\
\text { 996a ( } \\
\text { t al. } 19\end{array}$ & $\begin{array}{l}\text { rate per unit } \\
\text { plasma memb } \\
\text { human vascul } \\
\left(t_{1 / 2}\right) \text { in sheep } \\
\text { and in humar } \\
\text { BNP). }\end{array}$ & $\begin{array}{l}\text { Irified enzyn } \\
\text { s from shee } \\
\text { nooth musc } \\
\text { been taken } \\
\text { m Yandle } \epsilon\end{array}$ & $\begin{array}{l}\text { Ils (taker } \\
\text { the cur } \\
1986 \text { (A) }\end{array}$ & $\begin{array}{l}\text { m Suga et al. } 1 \\
\text { study (oBNP } \\
\text { McGregor et }\end{array}$ & $\begin{array}{l}3 N P \text { ) and } \\
0 \text { (oBNP }\end{array}$ & $\begin{array}{l}\text { es et al. } \\
\text { Holmes }\end{array}$ \\
\hline
\end{tabular}

was inconsistent with a preferential action of NEP on the receptor-bound hormone.

\section{Comparative rates of natriuretic peptide degradation}

The exceptionally small amounts of purified ovine and human NEP available precluded full determination of $K_{\text {cat }}$ and $K_{\mathrm{m}}$. Measurement of the enzyme degradation rate on standardised preparations, however, enabled a direct comparison between the ovine and human enzyme. When peptides were incubated with purified sheep NEP or human NEP, rates of degradation of hBNP differed markedly from those of ANP or oBNP (Table 1). Human BNP was not significantly degraded by either preparation of NEP. Similar findings were obtained with oNEP purified from sheep lung membranes. Absolute and relative degradation rates in sheep membrane preparations for ANP $(0.53 \mathrm{pmol} / \mathrm{min})$, oBNP $(0.10 \mathrm{pmol} / \mathrm{min})$ and hBNP $(0.02 \mathrm{pmol} / \mathrm{min})$ were in close agreement with those observed with the purified enzyme. ANP was consistently degraded more rapidly than oBNP by sheep NEP and by the human purified enzyme. These findings indicate that the unique structure of hBNP rather than the species form of the enzyme confers resistance to hydrolysis by NEP.

\section{Disappearance of BNP from plasma in vivo}

The disappearance rate $\left(t_{1 / 2}\right)$ of oBNP was $3 \cdot 0 \mathrm{~min}$ and $2 \cdot 1$ (median 2.6) $\mathrm{min}$ in two different sheep and similar to that previously reported in sheep (Charles et al. 1996a). In the same two sheep, $t_{1 / 2}$ of hBNP was $13.8 \mathrm{~min}$ and 11.5 (median 12.7) min respectively (Fig. 3, Table 1). As previously reported (McGregor et al. 1990), $t_{1 / 2}$ of oBNP in humans was $3 \cdot 1 \mathrm{~min}$.

\section{Discussion}

BNP secretion, a product largely of the ventricles, has been the focus of increasing interest for several reasons.
First, studies using rat cardiomyocytes show that BNP gene transcript activation and turnover are rapid (Hanford et al. 1994, Magga et al. 1997), suggesting that in contrast to ANP, BNP functions as a rapid response gene and may have unique paracrine functions. Increases in BNP transcripts in the human ventricle of patients with congestive heart failure or cardiac hypertrophy (Gerbes et al. 1994) exceed those of ANP. Further, the increase in plasma BNP concentrations above resting levels are proportionally greater in subjects with heart failure or following myocardial infarction than those of ANP (Espiner et al. 1995). Recent studies from several laboratories indicate that plasma BNP better reflects the severity of left ventricular dysfunction (Richards et al. 1999) as well as prognosis after myocardial infarction (Richards et al. 1998). Biological activity of BNP in humans is at least comparable to that of ANP, and in some studies more so (Pidgeon et al. 1996). Taken together these findings constitute compelling reasons for detailed study of BNP's metabolism, particularly since in humans the disappearance rate of hBNP from plasma is uniquely prolonged.

In previous in vivo studies in sheep (Charles et al. 1996a) we have shown that the $t_{1 / 2}$ of all three natriuretic peptides (ANP, oBNP and CNP) are similar (2-3 min) whereas in humans $t_{1 / 2}$ of hBNP (22 min) is some sevenfold greater (Holmes et al. 1993) than ANP, CNP (Espiner et al. 1995) or oBNP (McGregor et al. 1990). We reasoned that the uniquely prolonged half life of hBNP in humans may reflect a lower affinity of both NPR-C and NEP for hBNP, and have used the sheep (in which species endogenous natriuretic peptides are rapidly metabolised) to distinguish the separate contributions of enzyme and receptor to the metabolism of hBNP. Using ovine lung membranes and purified NEP we measured binding affinities and rates of hydrolysis of ANP and BNP forms, and related the findings to $t_{1 / 2}$ studies in sheep and humans. The binding affinity of ANP and oBNP for oNPR-C in lung membrane preparations was high $\left(K_{\mathrm{d}} 10-16 \mathrm{pM}\right)$, and similar to that found for these hormones in rat, bovine and human tissue preparations of NPR-C (Suga et al. 1992). However, in contrast to the lower binding affinity 


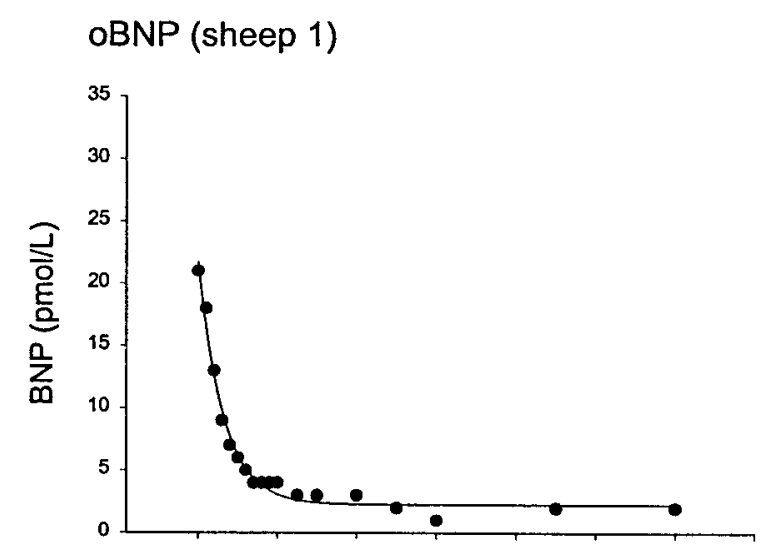

oBNP (sheep 2)

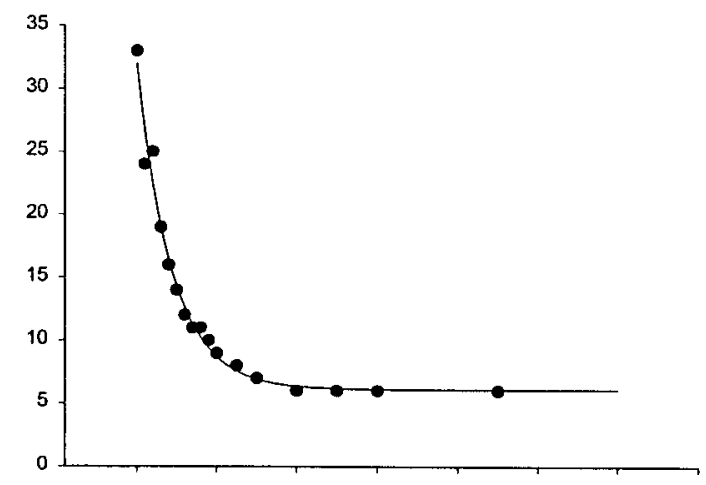

hBNP (sheep 2)

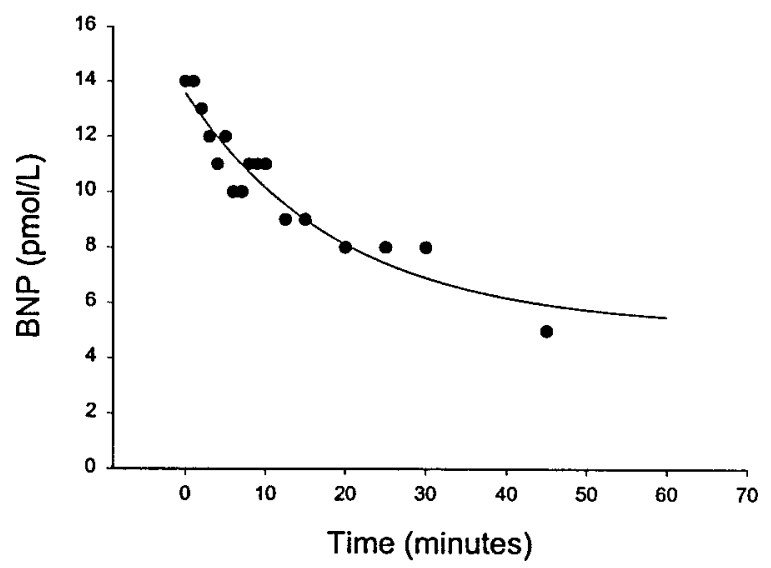

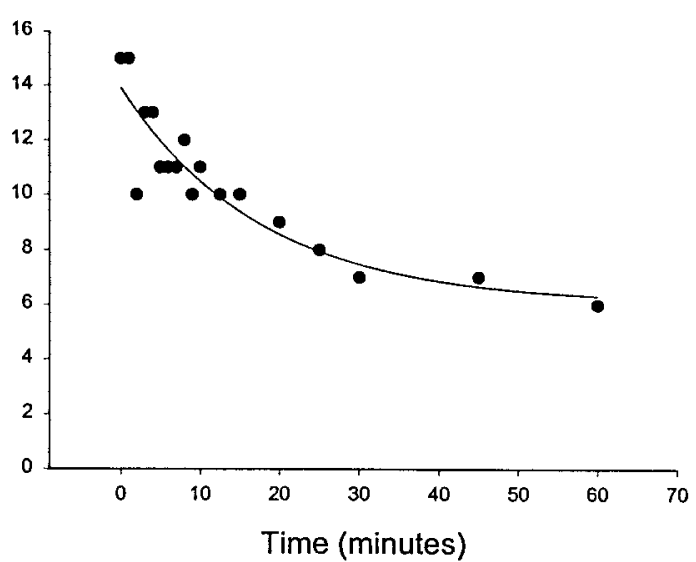

Figure 3 Disappearance of oBNP and hBNP from plasma in sheep 1 (left panels) and sheep 2 (right panels).

of hBNP for the hNPR-C (K $140 \mathrm{pM}$ (Suga et al. 1992)), oNPR-C binds hBNP with high affinity $\left(K_{\mathrm{d}} 8 \mathrm{pM}\right)$. These findings suggest that the oNPR-C retains an alanine residue at position 188, as reported for rat NPR-C (Engel et al. 1994). Interestingly, purified oNEP and ovine lung membrane NEP preparations both degraded ANP and oBNP but did not significantly degrade hBNP. The purified human enzyme (fully active against ANP and oBNP) also failed to degrade hBNP. From these findings we conclude that whereas in humans there is concordance in receptor and enzyme affinity (i.e. high affinity of both enzyme and receptor for ANP/oBNP, and low affinity of both for hBNP) this is not so in sheep where hBNP is bound with high affinity to oNPR-C yet is not a good substrate for ovine NEP. These combinations of findings have enabled us to interpret the separate effects of NPR-C and NEP in vivo for the first time. As shown in Table 1, whereas $t_{1 / 2}$ of ovine natriuretic peptides in sheep is short $(2-3 \mathrm{~min})$, the $t_{1 / 2}$ of $\mathrm{hBNP}$ is some fourfold increased. Our previous studies in humans showed a similar $t_{1 / 2}$ for ANP and oBNP ( $3 \mathrm{~min}$ ) but a prolonged $t_{1 / 2}(22 \mathrm{~min})$ for hBNP.
Thus whereas in the human the lower affinity of NPR-C and NEP for hBNP both contribute to the much prolonged $t_{1 / 2}$ of $\mathrm{hBNP}$, the current data suggests that despite high affinity of oNPR-C for hBNP the reduced ability of NEP to hydrolyse hBNP is associated with a relatively prolonged $t_{1 / 2}$ of hBNP in vivo. In fact, the $t_{1 / 2}$ for hBNP in sheep $(12.7 \mathrm{~min})$ lies midway between that of oBNP $(2.6 \mathrm{~min})$ and hBNP in humans $(22 \mathrm{~min})$, indicating that both degradative systems have the potential to participate equally in natriuretic peptide metabolism. Our findings also predict that the natriuretic peptide response to NEP inhibition will differ in the two species. This has recently been confirmed in vivo where, in contrast to the proportionate and equal response of both plasma ANP and BNP in sheep (Charles et al. 1996b, Rademaker et al. 1997), the response of plasma BNP to NEP inhibition in humans is much less than that of ANP (Lainchbury et al. 1999).

A second and related aim of our study was to examine the possibility of interactions between receptor and enzyme which, by increasing efficacy of NEP in tissues, may account for the unexpected activity of NEP inhibitors 
in vivo (Charles et al. 1991, Richards 1994). For example, local interaction between receptor and enzyme at the cell membrane - as reported to occur in the instance of substance P (Okamoto et al. 1994) - could make receptorbound hormone more susceptible to hydrolysis by NEP. Using sheep lung membranes (containing both high concentrations of NPR-C and an active NEP system) we found no evidence for such an interaction. Thus under conditions where NPR-C receptors were fully saturated, the $K_{\mathrm{m}}$ of the enzyme $(10 \mu \mathrm{mol})$ was comparable to that (30 $\mu \mathrm{mol})$ determined for the solubilised enzyme (Kenny et al. 1993). While not excluding an interaction between the receptor (including NPR-A) and enzyme in whole cell preparations, or an effect on catalytic rate, our findings point to other mechanisms. For example, preferential access of circulating hormone to NEP in the vascular endothelium (Llorens-Cortes et al. 1992) may help to explain the efficacy of NEP inhibitors in vivo.

Taken together, the above findings have important implications for treatment strategies aimed at increasing plasma BNP bioactivity in humans. In particular, our findings indicate that the highly effective combination of NPR-C and NEP blockade in sheep (Rademaker et al. 1997) - inducing marked increases in both endogenous ANP and BNP and consequential biological effects would not be expected in humans. For these reasons it will be important in humans to focus on other therapeutic strategies independent of alterations in NEP activity, for example measures exploiting the enhanced activity of hBNP analogues (Schoenfeld et al. 1997).

\section{Acknowledgements}

We thank Dr Gordon Porter, Scios Nova Inc., Mountain View, California for the monoclonal antibody to the human NPR-C, and Dr Paul Davis, School of Medicine, Wellington, New Zealand for gifts of purified renal endopeptidase. This work was supported by grants from the Health Research Council of New Zealand, the National Heart Foundation of New Zealand and the New Zealand Lottery Grants Board.

\section{References}

Aitken GD, George P \& Espiner EA 1994 Characterisation of ovine natriuretic peptide genomic DNA sequences (Abstract). Journal of Hypertension 12 (Suppl 3) S174.

Bates ER, McGillem MJ, Mancini J \& Grekin RJ 1989 Pulmonary extraction of immunoreactive atrial natriuretic factor in dogs. American Journal of Cardiology 63 372-373.

Charles CJ, Espiner EA, Yandle TG, Cameron VA \& Richards AM 1991 Biological actions of cleaved atrial natriuretic factor (ANF $101-105 / 106-126)$ in conscious sheep. Journal of Cardiovascular Pharmacology 17 403-410.

Charles CE, Espiner A, Richards AM, Nicholls MG \& Yandle TG 1996a Comparative bioactivity of atrial, brain, and C-type natriuretic peptides in conscious sheep. American Journal of Physiology 270 R1324-R1331.

Charles CJ, Espiner EA, Nicholls MG, Richards AM, Yandle TG, Protter A \& Kosoglou T 19966 Clearance receptors and endopeptidase 24.11: equal role in natriuretic peptide metabolism in conscious sheep. American Journal Physiology 271 R373-R380.

Espiner EA, Richards AM, Yandle TG, \& Nicholls MG 1995 Natriuretic hormones. Endocrinology Metabolism Clinics North America 24 481-509.

Engel AM, Schoenfeld JR \& Lowe DG 1994 A single residue determines the distinct pharmacology of rat and human natriuretic peptide receptor-C. Journal of Biological Chemistry 269 17005-17008.

Gerbes AL, Dagnino L, Nguyen T \& Nemer M 1994 Transcription of brain natriuretic peptide and atrial natriuretic peptide genes in human tissue. Journal of Clinical Endocrinology and Metabolism $\mathbf{8}$ 1307-1311.

Hanford DS, Thuerauf DJ, Murray SF \& Glembotski CC 1994 Brain natriuretic peptide is induced by $\alpha 1$-adrenergic agonists as a primary response gene in cultured rat cardiac myocytes. Journal of Biological Chemistry 269 26227-26233.

Hollister AS, Rodeheffer RJ, White FJ, Potts JR, Imada T \& Inagami T 1989 Clearance of atrial natriuretic factor by lung, liver and kidney in human subjects and the dog. Journal of Clinical Investigation 83 623-628.

Holmes SJ, Espiner EA, Richards AM, Yandle TG \& Frampton C 1993 Renal, endocrine, and hemodynamic effects of human brain natriuretic peptide in normal man. Journal of Clinical Endocrinology and Metabolism 76 91-96.

Kenny AJ, Bourne A \& Ingram J 1993 Hydrolysis of human and pig brain natriuretic peptides, urodilatin, C-type natriuretic peptide and some C-receptor ligands by endopeptidase-24-11. Biochemistry Journal 291 83-88.

Kittelberger R \& Neale TJ 1990 Isolation and characterization of an unique kidney antigen of relevance in human renal disease. Biochemical Biophysical Research Communications 172 439-445.

Lainchbury JG, Richards AM, Nicholls GM, Espiner EA \& Yandle TG 1999 Brain natriuretic peptide and neutral endopeptidase inhibition in left ventricular impairment. Journal of Clinical Endocrinology and Metabolism 84 723-729.

Llorens-Cortes C, Huang H, Vicart P, Gasc JM, Paulin D \& Corvol P 1992 Identification and characterization of neutral endopeptidase in endothelial cells from venous or arterial origins. Journal of Biological Chemistry 267 14012-14018.

Maack T, Okolicany J, Koh GY \& Price DA 1993 Functional properties of atrial natriuretic factor receptors. Seminars in Nephrology 13 50-60.

Maeda T, Balakrishnan K \& Mehdi SQ 1983 A simple and rapid method for the preparation of plasma membranes. Biochimica et Biophysica Acta 731 115-120.

Magga J, Vuolteenaho O, Tokola H, Marttila M \& Ruskoaho H 1997 Involvement of transcriptional and posttranscriptional mechanisms in cardiac overload-induced increase of B-type natriuretic peptide gene expression. Circulation Research 81 694-702.

McGregor A, Richards AM, Espiner EA, Yandle TG \& Ikram H 1990 Brain natriuretic peptide administered to man: actions and metabolism. Journal of Clinical Endocrinology and Metabolism 70 1103-1107.

Munson PJ \& Rodbard D 1980 Ligand: a versatile computerized approach for characterization of ligand-binding systems. Analytical Biochemistry 107 220-239.

Okamoto A, Lovett M, Payan DG \& Bunnett NW 1994 Interactions between neutral endopeptidase (EC 3.4.24.11) and the substance $\mathrm{P}\left(\mathrm{NK}_{1}\right)$ receptor expressed in mammalian cells. Biochemical Journal 299 683-693.

Okolicany J, McEnroe GA, Koh GY, Lewicki JA \& Maack T 1992 Clearance receptor and neutral endopeptidase-mediated metabolism 
of atrial natriuretic factor. American Journal of Physiology 263 F546-F553.

Pidgeon GB, Richards AM, Nicholls MG, Espiner EA, Yandle TG \& Frampton C 1996 Differing metabolism and bioactivity of atrial and brain natriuretic peptides in essential hypertension. Hypertension 27 906-913.

Porter JG, Silva M, Catalano R, Hummel P \& Scardina JM 1993 Monoclonal antibodies to the atrial natriuretic peptide clearance receptor from recombinant vaccinia virus infection. Program of the 75th Annual Meeting of The Endocrine Society, Las Vegas, p. 249 (Abstract). Bethesda, MD, USA: The Endocrine Society Press.

Rademaker MT, Charles CJ, Kosoglou T, Protter AA, Espiner EA, Nicholls MG \& Richards AM 1997 Clearance receptors and endopeptidase: equal role in natriuretic peptide metabolism in heart failure. American Journal of Physiology 273 H2372-H2379.

Richards AM 1994 The natriuretic peptide hormones and hypertension. Journal of Internal Medicine 235 543-560.

Richards AM, Nicholls MG, Yandle TG, Frampton C, Espiner EA, Turner JG, Buttimore RC, Lainchbury JG, Elliott JB, Ikram H, Crozier IG \& Smyth DW 1998 Plasma N-terminal pro-brain natriuretic peptide and adrenomedullin. New neurohormonal predictors of left ventricular function and prognosis after myocardial infarction. Circulation 97 1921-1929.

Richards AM, Nicholls MG, Yandle TG, Ikram H, Espiner EA, Turner JG, Buttimore RC, Lainchbury JG, Elliott JM, Frampton C, Crozier IG \& Smyth DW 1999 Neuroendocrine prediction of left ventricular function and heart failure after acute myocardial infarction. Heart 81 114-120.

Ruskoaho H 1992 Atrial natriuretic peptide: synthesis, release, and metabolism. Pharmacological Reviews 44 479-502.
Schoenfeld JR, Tom JYK \& Lowe DG 1997 Mutations in B-type natriuretic peptide mediating receptor-A selectivity. FEBS Letters $414263-267$.

Suga SI, Nakao K, Hosoda K, Mukoyama M, Ogawa Y, Shirakami G, Arai HH, Saito Y, Kambayashi Y, Inouye K \& Imura H 1992 Receptor selectivity of natriuretic peptide family, atrial natriuretic peptide, brain natriuretic peptide, and C-type natriuretic peptide. Endocrinology 130 229-239.

Watanabe Y, Nakajima K, Shimamori Y \& Fujimoto Y 1997 Comparison of the hydrolysis of the three types of natriuretic peptides by human kidney neutral endopeptidase $24 \cdot 11$. Biochemical Molecular Medicine 61 47-51.

Yandle TG, Richards AM, Nicholls MG, Cuneo R, Espiner EA \& Livesey JH 1986 Metabolic clearance rate and plasma half life of alpha-human atrial natriuretic peptide in man. Life Sciences $\mathbf{3 8}$ 1827-1833.

Yandle TG, Richards M, Smith M, Charles C, Livesey J \& Espiner EA 1992 Assay of endopeptidase-24.11 activity in plasma applied to in vivo studies of endopeptidase inhibitors. Clinical Chemistry $\mathbf{3 8}$ 1785-1791.

Yandle TG, Richards AM, Gilbert A, Fisher S, Holmes S \& Espiner EA 1993 Assay of brain natriuretic peptide (BNP) in human plasma: evidence for high molecular weight BNP as a major plasma component in heart failure. Journal of Clinical Endocrinology and Metabolism 76 832-838.

Received 21 March 2000

Accepted 28 June 2000 